\title{
The Impact of Economic Diplomacy on the Fulfilment of the Slovak Pro-export Policy Goals
}

DOI 10.18267/pr.2021.krn.4816.17

\author{
Viera Ružeková ${ }^{1}$ - Ján Hrinko² \\ ORCID iD: 0000-0002-2225-02251, 0000-0002-7041-3906² \\ viera.ruzekova@euba.sk, jan.hrinko@euba.sk \\ 1,2 University of Economics in Bratislava, Faculty of Commerce, Department of \\ International Business \\ Bratislava, Slovakia
}

\begin{abstract}
For the Slovak, highly open and export-oriented economy, foreign trade is an important factor of economic growth. In the current global economic environment, the process of interconnecting economic relations between countries is constantly growing and the professional economic diplomacy, as a part of the foreign trade policy of each economy, plays an important role. Therefore, the aim of our research was to use scientific research methods to assess the impact of the Slovak economic diplomacy on the fulfilment of pro-export policy goals. At the same time, we try to evaluate how the performance of economic diplomats and models of economic diplomacy affect the development of the economy and export performance. We also focused on examining the task of the innovative diplomacy.
\end{abstract}

Keywords: Trade policy, export performance, international business, economic diplomacy.

JEL Classification codes: F10, F14, F20

\section{INTRODUCTION}

The current world trade form is undoubtedly linked with an international division of labour. There is hardly a country excluded from or independent of international business characterised by high dynamics and great changes in the territorial and commodity structure. The international business growth, except low crisis deviations, has long been faster than world GDP growth. Between 1950 and 2020, the international business volume increased 60 times in the value expression and only 13 times in the physical expression, although the world GDP increased only 2 times. Between 1992 and 2015, an average pace of the export growth was almost 7 times faster than the GDP growth $(2,6 \%)$ as shown in the graph 1 (Baláž et al.,2020). Despite the economic growth demonstration, the global division of labour results in the division of the growth and consumption centres. The growth is noticeable in countries that produce more than consume, e.g., BRICS countries, and the consumption is observable in developed economies such as the US, EU or Australia, despite their arising problems to earn for their consumption.

Since the beginning of the $21^{\text {st }}$ century, the world economic development has been facing a new challenge represented by deglobalisation causing a high degree of uncertainty in the liberalised trade. The deglobalisation tendencies may result in greater imbalance between the countries, loss of jobs or widespread of poverty in the problematic regions (CIGI, 2017). All this makes conditions for economic crises to occur repeatedly. Competition for investments, sources of energy, jobs and market shares lead to the question of holding or rising power or survival of the state. The foreign trade represents a way of connecting and interconnecting the national economy with the international economic environment, including comparative 
advantages of the national economy and excluding its advantages. It creates an opportunity for state administration activities or business managers being responsible for the economic development of individual entities or the economy as a whole.

Fig. 1 World trade and GDP between 1960 \& 2020

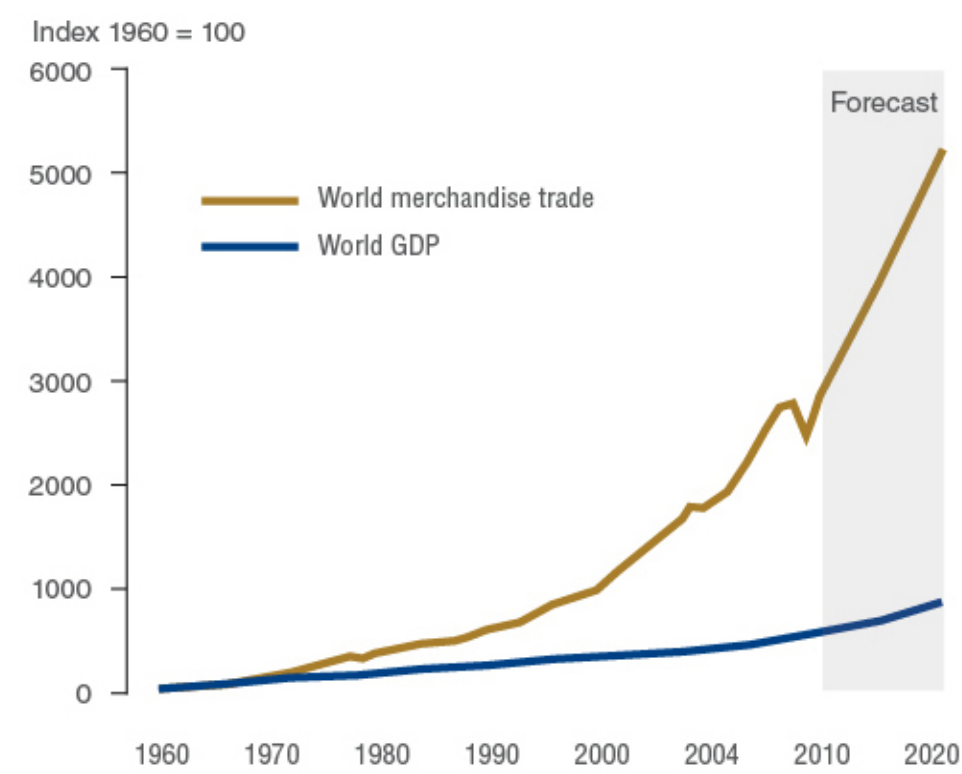

Source: Oxford Economics Report - The Economic Impact of Express Carriers in Europe

The international trade is no longer a matter of customs or business paths. It is the matter of state's intra-political security and stability. The economic diplomacy increases its prominence as it moves from the free trade policy to the militant forms of the international economic relations, i.e. economic warfare.

\section{LITERATURE REVIEW}

Under the influence of the globalisation, the $20^{\text {th }}$ and the beginning of the $21^{\text {st }}$ century saw new trends and quality changes in the world economy reflected in the international relations, international business and international trade. Industrial revolution caused decrease in production costs and increase in production volume exceeding the absorption ability of the domestic market (Baláž et al, 2020). The GDP increased and so did the export. A lot of world economists point at the direct relation with the GDP growth and the international trade growth (M. Porter, 2008),(A. Madisson, 2007) and demonstrate their improvement reflected in the world trade development and so in the international trade, foreign trade and vice versa. Positive development of foreign trade is an important indicator of economic growth, largely affecting effective functioning of the etire economy (Baláž, Zábojník, Harvánek, 2019). The export and import are enormous, both for the economies and businesses conducting their activities therein. For the producers, it means increase in the production, growth in profits and sources of sale. For the national economies, it represents revenues, increase in pensions and subsequently growth in savings, employment as well as aggregate domestic market (Kašt'áková, Ružeková, 2019). Slovakia is highly open economy due to its heavy dependence upon the foreign trade and significant sensitivity to the world economic environment changes. Developed industrial production is dependent upon raw materials imports on the one hand and is expected to sell its own production on the foreign markets due to relatively small internal market (Kittová \& Steinhauser, 2017). 
The export support may be described as a sum of tools and measures used via the third and superior party with the aim to facilitate the domestic exporters in making contacts with their foreign partners and concluding or conducting agreements (M. Csabay, 2007). An important role in the export support plays the economic diplomacy considered as an economic dimension of the foreign state policy and occupying a significant place in the diplomacy as such (Bayne,N., Woolcock, S. 2016). The economic diplomacy has always been an integral part of the classical diplomacy and as M. Csabay states, what makes it different from political economy is its relation or sensitivity to the market and its scope in the foreign economic and trade relations of the state (M. Csabay, 2007). Literature, whether domestic or international, offers a vast variety of definitions which may arise from preferences of their authors with academic or diplomatic practice. As OECD sets out, the economic diplomacy may be understood as a frame of support and services a state provides with its domestic entities with an aim to thrive on the foreign market (OECD, 2017). It is deeply integrated into the proexport policy conception of every market-oriented economy and its competences, branch foci, territorial interest priorities and institutional backgrounds arise from the comparative advantages of the national economy and its business-economic interests in the world (J. Štouračová, 2012). Traditionally, the economic diplomacy is viewed as decision-making, policymaking and advocating for business interests of the state. In K. Rana's words, it is a process through which countries tackle the outside world to maximise their national gain in all spectra of their activities, including trade, investment and other forms of economically beneficial exchanges where they enjoy comparative advantage; it has its bilateral, regional and multilateral dimensions, each being equally crucial (K. Rana, 2007).

In the $21^{\text {st }}$ century, the economic diplomacy gets confronted with new challenges individual states must adapt to. D. A. Degterev, a Russian expert in the diplomacy, points at a fact, the economic diplomacy is currently multicriterial and multilevel, and implies that the macroeconomic diplomacy is inseparably linked with the microeconomic diplomacy in such a manner that the former one makes international opportunities and function space for the latter one (D.A.Degterev,2007). Processes of the structural release, in the $21^{\text {st }}$ century related to the changes in globalisation, deglobalisation, technological as well as information and other ones, have affected multiplication of the parties to the international relations and diplomacy, including the economic diplomacy (Z. Veselý, 2011). While the classical diplomacy was exclusively the domain of the state authorities, undergoing changes in the economic diplomacy have brought new parties Bayne \& Woodlock divide into state parties and nonstate parties, both dynamically changing in the process of development. Assessment of the economic diplomacy participation and influence in achieving the proexport policy aims may be carried out via tasks and functions of the economic diplomacy. K. S. Rana distinguishes four pillars of the diplomat's economic diplomacy, i.e. export support, investment support, technology attraction and development aid management (Bayne a Woolcock , 2007). In Pajtinka's view, diplomat's tasks and functions are business relation support and development, investment support, economic-information and political-legislative function, assistance with development aid and country's promotion.

\section{METHODOLOGY}

One of the paper's aims is to assess the influence of the economic diplomacy on the achievement of the Slovak proexport aims. In order to achieve such an aim, a few theoretical methods were used, such as analysis and synthesis, induction and deduction as well as comparison. Subsequently, the Slovakia economic diplomacy is assessed in terms of the defined Slovak proexport policy aims between 2014 and 2019 ordered by the proexport policy, direct foreign investment support and innovation cooperation from abroad. Data was taken from the Slovakia's Statistical Office, Ministry of Economy and Ministry of Foreign and European 
Affairs. As Slovakia is currently adopting a new Slovak proexport policy concept, the paper focuses on the prediction of the Slovak export until 2025 using a correlation regression analysis as part of the scholastic modelling. The analysis enables to project changes in the future with certain probability. The data was taken from the Slovakia's Statistical Office and the World Bank (export of goods and services at constant prices) with regard to the Slovak export and GDP as well as the world GDP between 2010 and 2019. The dependent variable is represented by the Slovak export, the independent variable is represented by the values of the Slovak and world GDP at constant prices between 2010 and 2019. The determination coefficient $\left(R^{2}\right)$ expresses percentage of the dependent variable value variation $Y$ is a result of the independent variables variation $X$. The model predicts the development of the Slovak export between 2020 and 2025. The prediction of the Slovak future export development as well as the analysis of the achieved results for last years facilitate in defining the future aims, directing the proexport policy and optimising the number of the Slovak economic diplomats abroad.

\section{RESULTS AND DISCUSSION}

The Slovak economic diplomacy is an integral part of the state foreign policy and represents a coordination of the state and nonstate entities firstly focused on the support of the proexport policies and tools with the aim of creating the most optimal domestic economic environment and secondly focused on the emphasis of the task and capacity of the economic diplomacy in the transposition of the Slovak interests abroad. These activities should contribute to the growth in the economy as well as the increase in the competition, employment, export performance of the small-sized and middle-sized companies, investment attraction of Slovakia and unified presentation abroad. How the Slovak economic diplomacy thrives on achieving the aims is assessable via its quality and competitiveness and with regard to the strategy, aims, capacity, financial resources, quality of the services linked with the quality of the human resources, adequate territorial location of the embassies abroad etc. A lot of activities need not be measurable, however may contribute to the increase in the country's reputation and its position in the international political-economic environment.

In assessing the influence of the economic diplomacy on achieving the aims of the proexport policy, a few views, levels and econometric models may be considered. Clarification of the relation between the business activity and the presence of the embassies abroad is often achieved by using the gravity model or the so-called gravity equation published by W. Isard in 1954, later altered and in its present-day form first mentioned in the J. Tinbergen's paper. This model enables to clarify bilateral business flows between individual states based on their economic and geographical distance. For the purpose of our research, which is not aimed to assess the influence of the Slovak economic diplomacy at the bilateral level, but is aimed to assess the influence of the economic diplomacy on achieving the aims of the pro-export policy between 2014 and 2020, the research focuses on the aims defined in the pro-export policy and ordered by the general versus specific ones, the innovative diplomacy, territorial focus of the economic diplomacy and the optimisation of the Slovak economic ambassadors' number abroad.

\subsection{Assessment of general and specific pro-export policy aims}

The fundamental area for the bilateral economic diplomacy is represented by the foreign trade and investments. Slovakia is a state with heavy dependence upon the foreign trade and one of the most open economies. It is therefore obvious it is greatly influenced by major trends forming the world trade such as the technological advance, digitalisation, automation, 
sustainable development, climate changes, environment protection as well as demographical trends and economic nationalism.

Slovak external economic relations strategy between 2014 and 2020 in the export support area:

- $\quad$ general ones such as the growth in export and number of exporters as well as security of stable deliveries and strategic goods,

- $\quad$ specific ones such as the diversification of export territorial and commodity structure, increase in MSP export share and growth in export of services.

\section{General aim - Growth in export}

Slovakia is characterised by a high production ability and one of the most open economies (185,3 \% in 2019) considering the foreign trade and mainly the export an economic growth stimulus, an important factor in payment ability, international credibility, overall rating of the state. In the pro-export policy called the Strategy for the external economic relations between 2014 and 2020, the export aim was to secure the export growth, which may be viewed as very general, without quantification and thorough check or relevant and effective regulation measures.

\section{Fig. 2 Slovak foreign trade development between 2002 and 2019 (in millions EUR)}

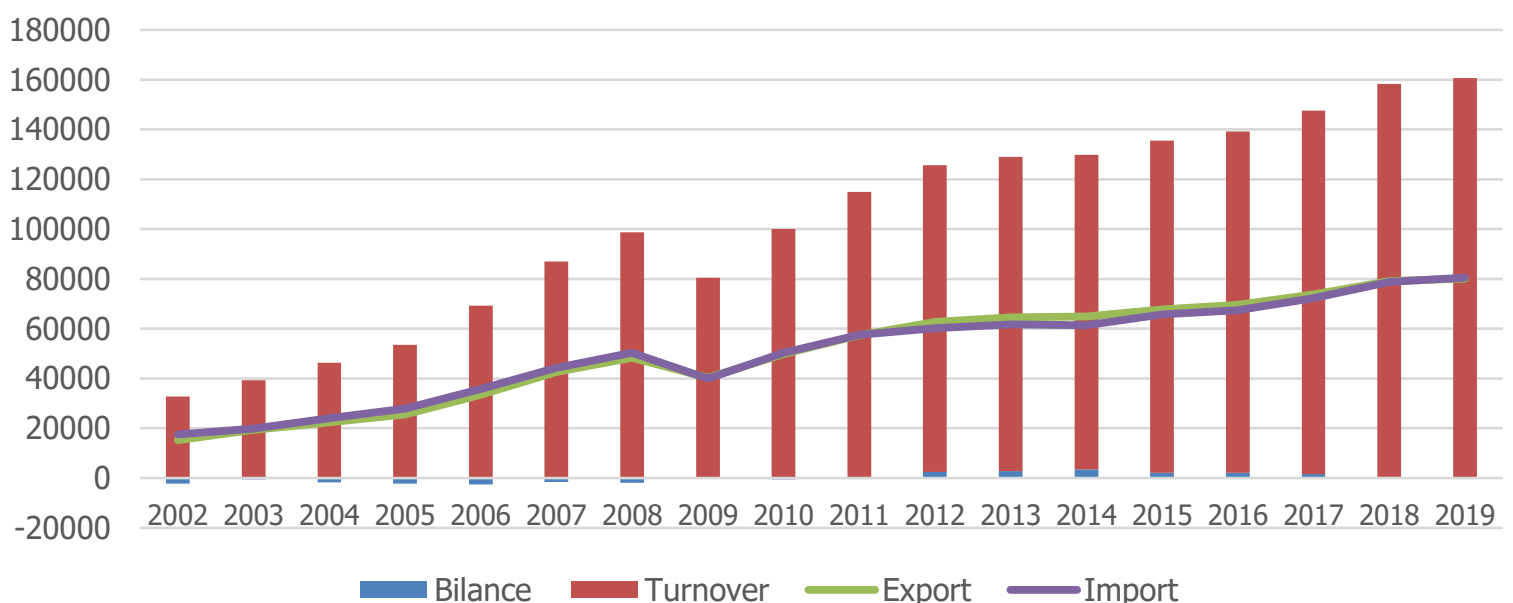

Source: processed by the author based on the data taken from WTO Merchandise imports by product group - annual, 2020.

As it is evident in the graph above, the export saw certain stagnation starting in 2012 and presumably lasting until today. It may be caused by unsuitable territorial and commodity structure of the Slovak foreign trade. At the beginning of the EU economic recession and at the time of the Slovak low-quality export, our significant orientation towards the EU markets resulted in the export performance increase.

Tab. 1 Export share in Slovakia and Czechia between 2012 and 2019 per capita (in EUR)

\begin{tabular}{|c|c|c|c|c|c|c|c|c|}
\hline & $\mathbf{2 0 1 2}$ & $\mathbf{2 0 1 3}$ & $\mathbf{2 0 1 4}$ & $\mathbf{2 0 1 5}$ & $\mathbf{2 0 1 6}$ & $\mathbf{2 0 1 7}$ & $\mathbf{2 0 1 8}$ & $\mathbf{2 0 1 9}$ \\
\hline SR & 12378,35 & 12864,48 & 12885,66 & 13538,29 & 13997,71 & 14799,32 & 15821,75 & 15919,14 \\
\hline ČR & 11707,38 & 11533,14 & 12303,67 & 12961,70 & 13300,03 & 14502,35 & 15299,48 & 15643,45 \\
\hline
\end{tabular}

Source: processed from data EUROSTAT, 2020 
To assess whether the export increased sufficiently is thus rather disputable. The Slovak export position may also be viewed in comparison with Czechia or with the average of the EU countries per capita as shown in Table 1.

The average export in the EU-28 in 2018 per capita was at the level of 12746 EUR. It is significantly lower than that in Slovakia, Czechia or other small economies regarding the number of their inhabitants. It is due to the fact that the EU comprises countries with significantly larger internal market, greater domestic consumption demand and unnecessarily orientation towards the export only.

The countries are aware of the export importance in the national economy and therefore endeavour to increase their export performance in the growing global competitiveness. It is noticeable at the level of their overall export as well as in the quality export area represented by the export of the sophisticated production, top technologies, increasing services share in the export and the pillar factors in the international competitiveness as described in details in the innovation diplomacy part.

\section{General objectives - Increase in the number of exporters / Increase in the share of SMEs in export of the Slovak Republic}

The evaluation of the indicator of growth in the number of exporters is possible in this section, as well as within the specific objectives, in the section Increase in the share of SMEs in total exports. In our research, we will make an evaluation in this section.

Small and medium-sized enterprises (SMEs) represent a key prerequisite for economic growth and development. In 2019, SMEs in the Slovak Republic accounted for $99.9 \%$ of the total number of business entities, employed more than $2 / 3$ of the active labour force and contributed more than half to the creation of added value. In the realm of export support for SME entities, the Slovak Republic has long been trying to increase not only their number, but also the value of their exports. Given that the Ministry of Economy of the Slovak Republic did not quantify this goal in the Strategy of External Economic Relations for 2014 - 2020 (i. e. it was not defined what the desired percentage of increase is), the evaluation of the achieved results is disputable. For example, the Czech Republic quantifies precisely that from 2016 to 2020 it is desirable to increase the number of exporting companies by $15 \%$.

According to the data of the Statistical Office of the Slovak Republic, the number of exporting SMEs reached 31,299 in 2019, while in 2014 it was only 26,000, i. e. the number of exporting SMEs increased by $6.4 \%$. In absolute terms, the number of exporting SMEs increased by almost 2,000 compared to 2014. However, if we compare the share of SMEs in the total exports of the Slovak Republic, then it was at the level of 28\% in 2019 and $26.7 \%$ in 2014, which cannot be considered as meeting the goal. Therefore, the lack of competitiveness of SMEs persists at the international level. The result is a long-term dominance of large companies in foreign trade in goods, with a predominance of the automotive sector and SMEs focusing more on the domestic market. Due to the anti-epidemic measures taken that adversely affect the performance of SMEs, it is not possible to expect an increase in the share of SME exports in total Slovak exports in the near future.

In terms of territorial structure of exports of SMEs in Slovakia it has long reflected the dominance of the EU market, where up to $90.7 \%$ of SME exports went in 2019. Within the commodity structure of SME exports dominated the export of machinery, apparatus, electronic equipment (32.4\%), metals and their products (16.0\%), vehicles, aircraft, transport equipment $(10.4 \%)$ in 2018 . Regarding the export of high-tech production, the participation of SMEs in the export of this category of products reached a share of $27.5 \%$ in 2019 . The workforce flexibility and the high motivation and orientation towards performance on the owners' side are considered to be decisive strengths. The general advantages of SMEs are also their knowledge of the local market, as well as their ability to respond flexibly to developments in 
the local environment. Among the main weaknesses of Slovak SMEs are the production of products with high energy intensity, lack of state orientation to support SMEs, backwardness in new technologies, lack of knowledge and experience in management and marketing, predominance of low value-added production, as well as insufficient investment corporate finance in the field of intellectual property.

\section{General objectives - Securing stable supply of strategic goods}

Securing a stable supply of strategic goods is linked to securing supplies within the food and energy security of the state. From 2014 to 2020, in a field of energy security was special attention paid to the development of interconnection of gas and oil pipelines between EU countries in order to increase the security and stability throughout the EU economy. The Slovak Republic participates in the fulfilment of this goal within the framework of the EU's Common Commercial Policy and multilateral diplomacy. Due to more than $90 \%$ dependence on the supply of energy carriers, the Slovak Republic is very active and is working on the implementation of the so-called projects of common EU interest (PCI) in the gas, electricity and oil industries. Great attention is paid to the diversification of sources, transport routes and minimization of risks in the event of a supply failure of particular raw materials or goods. Economic diplomacy is helpful in this regard in the structures of the European Commission, the Ministry of Economy of the Slovak Republic and the Ministry of Foreign and European Affairs of the Slovak Republic. Due to existential necessity, this goal is long-term and is also a part of the Concept of External Economic Relations and Economic Diplomacy of the Slovak Republic for 2021 - 2030.

In the realm of food security, despite the problem of food self-sufficiency, Slovakia is among the above-average qualitatively in the global comparison. The problem is the low share of Slovak food products in stores, which stagnates in the monitored period and reaches less than $40 \%$. In comparison, the level of food security from own production in Switzerland, for example, has long been in the range of 59 to $64 \%$, in Germany it has not dropped below $94 \%$ for a long time. On the other hand, Slovak foreign trade in agri-food products is declining. Exports are falling, imports are rising. The Slovak Republic achieve the largest trade deficit in agro-commodities in food, beverages and tobacco, where imports increased by EUR 145.5 million between 2018 and 2019. For example, imports of animal products also increased by almost EUR 54 million. This trend is unsustainable, but it is not primarily associated with the fulfilment of the goals of economic diplomacy, but of the Ministry of Agriculture and Rural Development of the Slovak Republic.

\section{Specific objectives - Diversification of the territorial and commodity structure of exports}

The objectives of the Strategy in the realm of diversification of the territorial and commodity structure of Slovak exports were not fulfilled, even though they were among the strategic objectives. In assessing diversification, we compared the territorial structure of Slovak exports in 2014, as the base year and 2019. It emerges from them that the share of exports from the Slovak Republic to the EU markets reached 83.9\% in 2014 and in 2019 it reached an even higher level of $84.2 \%$. This fact poses a great risk to our economy. At a time of economic recession in the EU, Slovak producers do not have established sales markets outside the EU, which would pull our economy in times of crisis and mitigate the negative impact of the recession of EU economies. Economic diplomacy has relatively large reserves in this area. This should be the content of the agenda of cooperation between economic diplomacy, the business sphere and the territory of operation within B2B - Business to Business activities, as well as G2G - Government to Government. A more detailed overview of the territorial structure of Slovak exports in 2014 and 2019 is given in Chart 2. 
Fig. 3 Territorial structure of Slovak exports in 2014 and 2019 (in \%)
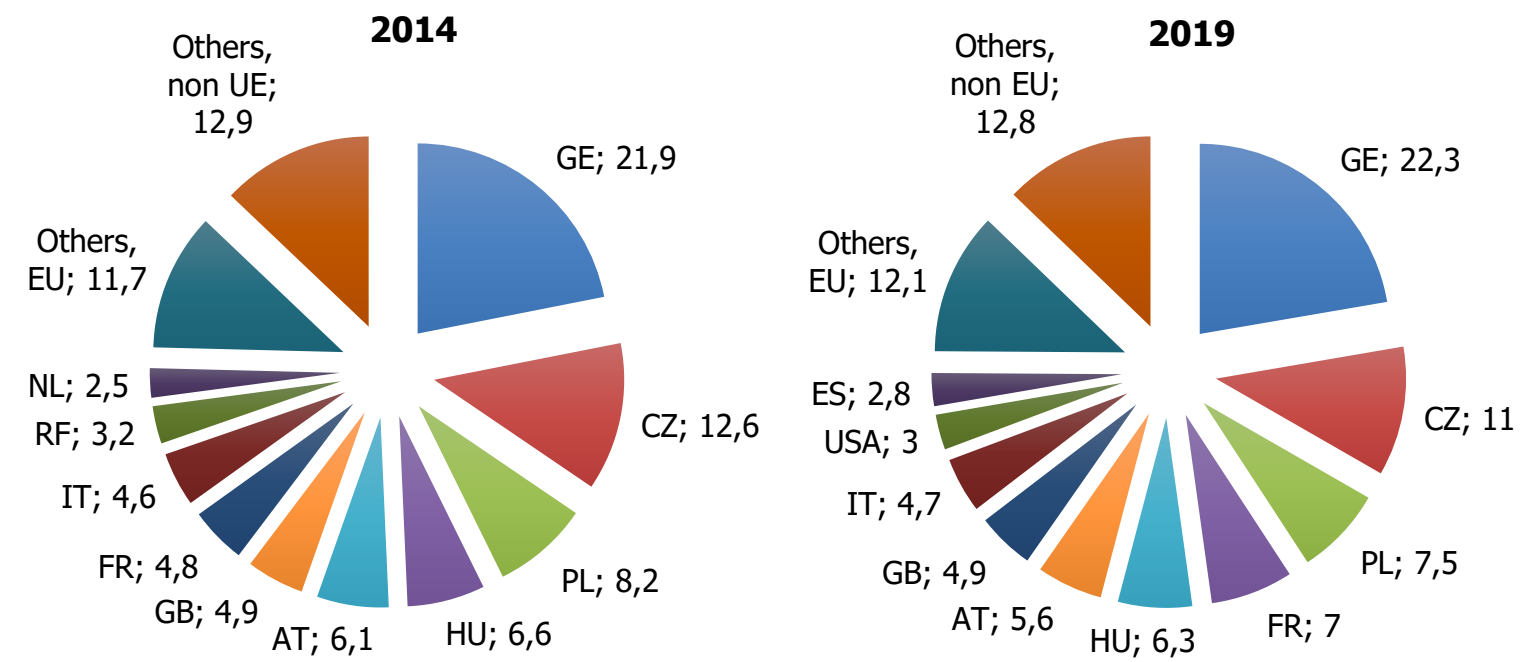

Source: processed from data of the Statistical Office of the Slovak Republic Data Cube - Statistics ZO HOS4, 2020

The diversification of the commodity structure of Slovak exports, as well as the territorial structure, is unsatisfactory. The inflow of foreign investment in the automotive and electrical engineering industries was a major boost after 1993. However, what was an advantage in the early 1990s, in the form of reduced unemployment, growth in exports and state budget revenues, became a problem in the second decade of the new millennium. The long-term dominant position of the automotive industry, which is the backbone of our national economy with a $50 \%$ share of industrial production and a $13 \%$ share of the country's GDP, appears to be a threat to our economic development and international competitiveness. Today, the automotive industry directly employs 135,000 , secondary up to 250,000 workers, with an annual output of more than 1.1 million automobiles. The mistake was and still is that the automotive industry was not complemented by the development of science and research, the creation of new sophisticated industries with high added value, which would speed up the production and subsequent export of high technologies. A comparison of the commodity structure of Slovak exports in 2019 to the base year 2014 is shown in Chart 3

While in 2014 only three product groups accounted for up to $58 \%$ of our exports, in 2019 their share increased even more and reached $63 \%$. The achieved state does not correspond to the goals of pro-export policy and the tasks of economic diplomacy as well as directly threatens the economic security of our economy. This situation in times of recession in target market economies can lead to a significant cooling or even collapse of our economy. We had the opportunity to experience the veracity of this statement during the global financial crisis in 2008-2009, when the annual decline in our exports reached almost $20 \%$ and has been proving problematic in recent years. The production and export of these goods is carried out by a small group of several large multinational corporations, without the participation of economic diplomacy. Here as well, and in the case of territorial diversification, the B2B and G2G agenda is needed in economic diplomacy. 
Fig. 4 Comparison of the commodity structure of Slovak exports in 2014 and 2019 (in \%)

2014

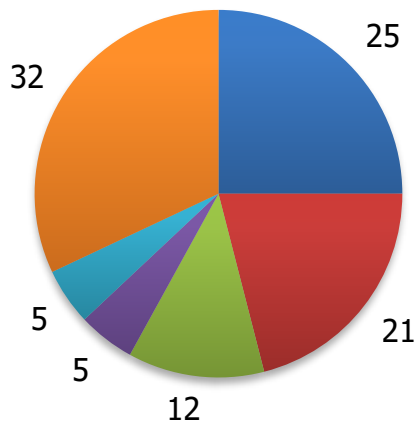

- Vehicles and their parts

- Machinery and eq.

Mineral fuels and oils

\author{
El. mach. and eq. \\ Iron and steel \\ - Others
}

2019

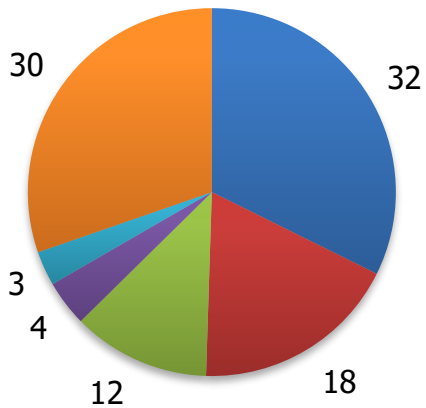

- Vehicles and their parts

- Machinery and eq.

El. mach. and eq.

- Iron and steel

others

Source: processed from data of the Statistical Office of the Slovak Republic Data Cube - Statistics ZO HS4, 2020

\section{Specific objectives - Growth in services export}

The country's success in international markets is not only due to the growth and support of exports of goods, but also to increasing the share of services in the country's total exports. This is also confirmed by the long-term efforts of individual economies to increase the share of services in total exports, through their pro-export policies. Export of services from the Slovak Republic has an increasing tendency. While in 2014, the export of services was worth EUR 9,062 million, in 2019 it was EUR 12,010 million. The largest share in the total export of services was carried out in the category of transport services and tourism with a share of less than $60 \%$. Services of a commercial nature have a decisive share, accounting for $99.6 \%$ of exports of services in 2019. The remaining percentages are for non-commercial services. The share of exports of services needs to be significantly increased in the coming years.

\subsection{Innovation diplomacy}

The Slovak Republic has long declared an effort to increase the quality of exports. This can be achieved by increasing human capital and creating an innovative environment that will strengthen the competitiveness of production and contribute to a qualitative shift in the value chain of Slovak exports. Despite our efforts, however, we have long been among countries with a weak innovation environment and low support for science and research. Within the EIS (European Innovation Scoreboard), the Slovak Republic belongs to the category of "moderate innovators" and in the Global Innovation Index, the Slovak Republic ranked 39th (the lowest of the V4 countries).

The improvement of the situation is conditioned by significant investments in the areas of innovation, science and research, to building a competitive knowledge-based economy. In the External Economic Relations Strategy for 2014 - 2020, the Slovak Republic has defined in this area the goal of "significantly increasing the share of high-tech production in total exports" with the significant participation of economic diplomacy as well. Realistic view on the development of exports high-tech products and their share in overall exports is given in Table 2 , which is complemented by the data for the EU (for better orientation). 
Tab. 2 Share of high-tech exports in total exports in the EU and the Slovak Republic in 2011 - 2019 (in \%)

\begin{tabular}{|l|c|c|c|c|c|c|c|c|c|}
\hline & $\mathbf{2 0 1 1}$ & $\mathbf{2 0 1 2}$ & $\mathbf{2 0 1 3}$ & $\mathbf{2 0 1 4}$ & $\mathbf{2 0 1 5}$ & $\mathbf{2 0 1 6}$ & $\mathbf{2 0 1 7}$ & $\mathbf{2 0 1 8}$ & $\mathbf{2 0 1 9}$ \\
\hline EU-28 & 15.4 & 15.7 & 15.3 & 15.6 & 17.0 & 17.9 & 17.8 & 17.9 & 16,1 \\
\hline SK & 6.6 & 8.2 & 9.6 & 9.9 & 10.0 & 9.7 & 10.6 & 9.6 & 10.0 \\
\hline
\end{tabular}

Source: Processed from data EUROSTAT, 2020 and from data WORLDBANK. 2021. High-technology exports (\% of manufactured exports).

It is evident that the Slovak Republic is well below the EU average. In the monitored period 2014 - 2019, the share of sophisticated production did not increase, on the contrary, it decreased! This indicator goes hand in hand with the intensity of spending and state support for science and research, education, involvement in international science and innovation projects. In the absence of not most positive information about the innovation performance of the Slovak Republic, we decided to analyse these shortcomings deeper. For this purpose, we used an indicator of the intensity of expenditure on science and research and their share in total GDP. The export of cutting-edge technologies is significantly influenced by the quality of scientific research activities in the country, associated with the support of science, research and innovation through private as well as government spending. Table 3 shows data processed in the EU-28 and separately for the Slovak Republic from 2010 to 2019.

Tab. 3 Intensity of expenditures on science and research in the EU and the Slovak Republic in 2011 - 2019 (\% / GDP)

\begin{tabular}{|l|c|c|c|c|c|c|c|c|c|}
\hline & $\mathbf{2 0 1 1}$ & $\mathbf{2 0 1 2}$ & $\mathbf{2 0 1 3}$ & $\mathbf{2 0 1 4}$ & $\mathbf{2 0 1 5}$ & $\mathbf{2 0 1 6}$ & $\mathbf{2 0 1 7}$ & $\mathbf{2 0 1 8}$ & $\mathbf{2 0 1 9}$ \\
\hline EU-28 & 1.96 & 2 & 2.01 & 2.02 & 2.03 & 2.04 & 2.08 & 2.12 & 2,14 \\
\hline SK & 0.66 & 0.8 & 0.82 & 0.88 & 1.16 & 0.79 & 0.89 & 0.84 & 0.82 \\
\hline
\end{tabular}

Source: processed from data EUROSTAT, 2020

The common goal within the EU was for investment in science and research in the EU to be at least $3 \%$ of GDP by 2020 . Only Sweden (3.31\%), Austria (3.17\%), Germany $(3.13 \%)$ and Denmark $(3.03 \%)$ managed to meet this target. Expenditures on science and research in the Slovak Republic represented only $0.82 \%$ of the total level of GDP in 2019, while the government's goal was for the intensity of expenditure on science and research to reach $1.2 \%$ of GDP by 2020. We can state that the support of science and research in the Slovak Republic is weak and falling behind, not only within the EU but also within the V4 countries. Insufficient state support in this area is already reflected in the reduction of the export performance of the Slovak Republic, the stagnation of the economy and the reduction of revenues to the Slovak Republic. The concept of smart industry (Industry 4.0) until 2030 must therefore be considered a priority, and good-quality economic diplomacy can be very helpful in this regard.

\subsection{Scope of economic diplomacy in the Slovak Republic}

The Ministry of Foreign and European Affairs of the Slovak Republic (MZVaEZ SR) is responsible for Slovakia's relations with foreign countries, whose task is to monitor global economic trends and challenges that may have a major impact on the economic development of our country. MZVaEZ SR is an important communication channel for the transmission of information on innovative approaches and proposals for solving urgent global economic challenges, whether at the multilateral level (within the UN, EU, OECD, etc.), the national level or the level of non- 
governmental organizations. It strives to act in such a way that the interests of the Slovak Republic are promoted uniformly, comprehensively and effectively.

The institutional framework of Slovak economic diplomacy was represented by a network of 89 embassies in 2020, whose task was to implement the Strategy of External Economic Relations of the Slovak Republic for 2014 - 2020 abroad. The number of economic diplomats has been steadily declining since 2011. While in 2011 there were 59 economic diplomats abroad, in 2020 it was only 36 and a further reduction is expected in 2021, only 31 independent economic diplomats will work abroad, who should fully perform tasks in promoting the economic interests of the Slovak Republic in abroad and provide services to Slovak business entities. For comparison, the Czech Republic has up to 124 economic diplomats abroad, Hungary about 140, Denmark 105! As foreign trade is crucial for the Slovak Republic and its economy, this situation is even more alarming if the activities of economic diplomacy can bring real results and support to domestic companies and the economy, which is subsequently reflected in the revenue component of the state.

\section{Territorial focus of economic diplomacy}

Based on the findings so far, in the next part of the article we will focus on predicting the development of Slovak exports until 2025, for which we used correlation-regression analysis within stochastic modelling, which will allow us to project changes in the future with a certain probability.

Tab. 4 Regional forecast of the increase in Slovak exports until 2025 and the link to the network of economic diplomats

\begin{tabular}{|l|c|c|c|c|}
\hline Regional group & $\begin{array}{c}\text { Increase 2019- } \\
2025 \text { (EUR mil.) }\end{array}$ & $\begin{array}{c}\text { \% share on } \\
\text { increase }\end{array}$ & $\begin{array}{c}\text { Number of } \\
\text { independent } \\
\text { economic diplomats } \\
\text { in 2020 }\end{array}$ & $\begin{array}{c}\text { Proposed } \\
\text { number of } \\
\text { independent } \\
\text { economic } \\
\text { diplomats by } \\
2025\end{array}$ \\
\hline EU (EU-27) & $\mathbf{+ 1 1 , 0 2 1}$ & $88.24 \%$ & 11 & 15 \\
\hline $\begin{array}{l}\text { Europe (excluding EU } \\
\text { countries) }\end{array}$ & $\mathbf{+ 6 3 5}$ & $5.08 \%$ & 5 & 6 \\
\hline Asia & $\mathbf{+ 4 2 0}$ & $3.37 \%$ & 6 & 9 \\
\hline CIS & $\mathbf{+ 1 5 7}$ & $1.26 \%$ & 6 & 7 \\
\hline Africa & $\mathbf{+ 9 6}$ & $0.77 \%$ & 2 & 4 \\
\hline Latin America & $\mathbf{+ 8 9}$ & $0.71 \%$ & 3 & 3 \\
\hline Middle East & $\mathbf{+ 7 9}$ & $0.63 \%$ & 1 & 4 \\
\hline North America & $\mathbf{+ 2 6}$ & $0.21 \%$ & 2 & 0 \\
\hline Australia and Oceania & $\mathbf{- 3 5}$ & $-0.27 \%$ & 0 & $\mathbf{5 2}$ \\
\hline Total & $\mathbf{+ 1 2 , 4 8 8}$ & $\mathbf{1 0 0 \%}$ & $\mathbf{3 6} *$ & 4 \\
\hline
\end{tabular}

* Out of the total number of 36, 2 posts (Moscow and Pretoria) have been vacant for a long time and 3 posts (Nairobi, Ljubljana and Stockholm) will be abolished in 2021 due to optimization.

Source: Concept of External Economic Relations and Economic Diplomacy of the Slovak Republic for 2021 - 2030, MZVaEZ 2020, internal material 
The model, as we described it in the methodology section, predicts the development of Slovak exports for 2019 - 2025 (Table 4, column 1), which together with the analysis of results achieved in recent years will help us in defining future priorities of pro-export policy, optimizing the number of economic diplomats abroad by 2025, as well as determining the territorial focus of economic diplomacy. The forecasted increase in exports in $2019-2025$ is at the level of EUR $+12,488$ million, which corresponds to the proposed minimum number of economic diplomats to 52 in 2025, which in the international comparison of the number of economic diplomats working abroad from other EU countries seems to be insufficient. The territorial focus of economic diplomacy is based on export, investment, scientific research and innovation priorities and goals, and last but not least it must reflect the real possibilities of economic diplomacy to influence the export efforts of Slovak companies. In terms of the territorial focus of economic diplomacy by 2030, the EU-27 markets will continue to be of the utmost importance, with smaller shares accounting for new promising third country markets.

The forecast of export growth by 2025 and the link to the economic diplomacy network is given in Table 4. The export forecast is adjusted for TOP 6 export commodities, as these are carried out not by Slovak companies, but by multinational companies operating in Slovakia and without the participation of Slovak economic diplomacy.

\section{CONCLUSION}

For the Slovak, highly open and export-oriented economy, foreign trade is an important factor of economic growth. It has an irreplaceable role in ensuring the optimal balance of internal reproduction processes, adapting economy to the conditions in foreign markets, and at the same time provides space for the application of effective trade policy instruments in order to increase international competitiveness. The Government of the Slovak Republic is aware of this, as it defined in its pro-export policy for 2014-2020 the goals that should have contributed to the growth of our economic competitiveness in the international environment. In this process, the economic diplomacy represents an important "extended hand" of the government, which promotes the interests of the Slovak Republic in a wide range of areas ranging from attracting investments, export support, presentation of research potential, involvement of companies in development cooperation to presentation of the country and its tourist potential. The aim of our research was to use scientific research methods to assess the impact of economic diplomacy on the fulfilment of pro-export policy goals.

In terms of our research, the quality of Slovak foreign trade can be assessed as moderate. Although we manage to maintain an active foreign trade balance, it is evident that the growth rate of exports and export performance is the result of our participation in global and especially regional value chains, rather than our own production. Since 2012, our exports have more or less stagnated, our territorial and commodity diversification is not sufficient, which can cause major problems at some point. As much as $85 \%$ of exports head to EU markets, which can decimate our economy in the event of an economic recession in these markets. The commodity structure of Slovak exports is significantly dominated by the output of multinational companies operating in Slovakia with lower domestic value added. The rate of involvement of Slovak SMEs in exports is low, as well as the share of high-tech products in our exports, reaching only about half the EU average. As the intensity of expenditures on science and research in the Slovak Republic is extremely low, at the level of only about $40 \%$ of the EU average, no significant progress can be expected in this direction in the near future. The share of the services sector in total exports is also low. Despite these negatives, with the help of scientific forecasts, we expect continuous growth of exports until 2025 with a forecast increase of 12,488 mil. EUR compared to the base year 2019. 
In the field of economic diplomacy, there is no single general approach to ensure its performance. However, there are several principles, each of which has its own challenges and should correspond to both international commitments and the needs of economy. The manager of economic diplomacy in the Slovak Republic is the Ministry of Foreign Affairs of the Slovak Republic, which states in the Concept of External Economic Strategy and Economic Diplomacy of the Slovak Republic until 2030 that "highly competitive environment and current global trends dwell a great emphasis on new innovative tools to support economic diplomacy and especially on new sectors with added value (green technologies, biomedicine, innovation, digitization or robotization). Economic diplomacy needs to present and communicate existing tools in a more targeted way and seek effective coordination with the remaining state and non-state actors in the field of $R \& D$. "However, these intentions are in conflict with reality, namely the gradual reduction of the number of Slovak economic diplomats abroad, from 59 economic diplomats in 2011 to 31 diplomats in 2021, who can hardly participate well in the above-mentioned intentions, including active innovative diplomacy. For example, the Czech Republic has 124 economic diplomats abroad.

The continuity of the reduction is critical and incomprehensible, when the Slovak Republic literally lives on foreign trade, investment and international cooperation. Due to financial under sizing in the field of economic diplomacy, its cumulative performance with another diplomatic agenda is increasingly being enforced, without sufficient knowledge of the economic agenda. Whereas economic diplomacy in the 21st century will face various challenges arising from the changed global economy, the performance of economic diplomacy must adapt to accordingly. In order to increase the quality and competitiveness of economic diplomacy in the Slovak Republic, it will be necessary to ensure its co-financing and increase the number of economic diplomats abroad, strengthen them with a group of sector-oriented diplomats for science, innovation research with adequate education and experience, expand their network in new promising territories. We must not forget to strengthen the so-called the soft power of diplomacy, while difficult to measure, can contribute to a country's attractiveness in an international context - as a good place to do business, as a place where people want to visit, invest, work and travel.

\section{REFERENCES}

Baláž, P. et al (2010). Medzinárodné podnikanie. Na vlne globalizujúcej sa svetovej ekonomiky, 5. prepracované a doplnené vyd. Sprint dva, Bratislava.

Baláž, P., Zábojník, S., \& Harvánek, L. (2019). Chinas Expansion in International Busines. The Geopolitical Impact on the World Economy. Cham: Palgrave Macmillan/Springer Nature, p. 335

Bayne, N. \& Woolcock, S. (2016). The New Economic Diplomacy. Decision-Making and Negotiation in International Economic Relations. Published, 2016 by Routledge 11 B/W Illustrations. p. 340.

Bergstrand, J.H. \& Egger, P.(2011) Gravity Equations and Economic Frictions in the World economy. In: Palgrave handbook of internationale trade. pp. 532-564.

CIGI. (2017). Deglobalization as a Global Challenge. online. Retrieved 14 February 2021, from https://www.cigionline.org/sites/default/files/documemnts/Paper\%20no.135WEB_1.pd.

Csabay, M. (2007). Mikro i Makroekonomičeskaja diplomacija: teorija i praktika. 2007. In: Zborník naucnych trudov po itogom NIR 2007 goda. Retrieved 14 February 2021, from http://mgimo.ru/files/34666/34666.pdf. 
Dubravská, M. (2019). Food safety of the Slovak Republic. Journal of Global Science. ISSN: 2453-756X. Retrieved 14 February 2021, from http://www.jogsc.com/pdf/2019/special/potravinova.pdf.

Kaštáková. E. \& Ružeková. V. (2019). International business operations. Bratislava. ed. EKONÓM.

Kittová, Z., \& Steinhauser, D. (2017). Inštitucionálne a makroekonomické prostredie firiem. Politická ekonomie, 65(2), 234-248. https://doi.org/10.18267/j.pep.1138

Kmoníček, Z. (2001). Origin and comparison of national export support systems in selected countries (1), (2) and (3). Banking, no. 7 - 8, p. 38 - 39; no. 9, pp. 30 - 32; no. 10, p. 34 - 36. In M. Csabay, 2007. On the theoretical definition of export promotion. Economic Magazine, 55., 793-810, Retrieved $14 \quad$ February 2021, fromhttps://www.sav.sk/journals/uploads/0929113708\%2007\%20Csabay.pdf.

Madisson. A. (2007). The World Economy: A millennial perspective. Organization for Economic Cooperation and Development. OECD Development Centre Studies.

MZVaEZ. (2016). Focus of economic diplomacy in the field of bilateral and multilateral relations until 2020. Retrieved 15 February 2021, from https://rokovania.gov.sk/RVL/Material/21556/1.

MZVaEZ. (2020). Internal material. The concept of external economic relations and economic diplomacy of the Slovak Republic for the period 2021 - 2030

OECD. (2017). Responsible business conduct and economic diplomacy tools. Retrieved 15 February 2021, from https://mneguidelines.oecd.org/Responsible-business-conduct-andeconomic-diplomacy-tools.pdf.

Pajtinka, E. (2007). Economic diplomacy and its role in the 21st century. International Relations, 42(4). Retrieved 15 February 2021, from http://mv.iir.cz/article/view/278?.

Porter, M. (2008). Competitive Advantage: How to create and maintain above-average performance. Prague: Victoria Publishing

Rana, K. (2002): Bilateral Diplomacy. Malta: DiploProjects, Mediterranean Academy of Diplomatic Studies, p. 283.

Rana, K. (2007). Economic Diplomacy: The Experience of Developing Countries'In: The New Economic Diplomacy: Decision Making and Negotiations in International Relations, eds. Nicholas Bayne and Stephen Woolcock, (Ashgate, London, 2nd Edition, 2007), pp. 201-220.

SBA. (2020). Small and medium-sized enterprises in numbers in 2019. Retrieved 16 February 2021, from http://monitoringmsp.sk/wp-content/uploads/2020/07/MSP_v_cislach_2019.pdf.

Štouračová, J. et al. (2012). Changes in economic diplomacy in the Czech Republic and in the world. Professional Publishing, Príbram.

Veselý, Z. Diplomacy (Theory-practice-history). Plzeň: Aleš Čeněk. pp. 61- 63. 